\title{
Evidence of nitrification and denitrification in high and low microbial abundance sponges
}

\author{
Marie-Lise Schläppy $•$ Sandra I. Schöttner • \\ Gaute Lavik • Marcel M. M. Kuypers • \\ Dirk de Beer • Friederike Hoffmann
}

Received: 13 February 2009/Accepted: 6 November 2009/Published online: 24 November 2009

(C) The Author(s) 2009. This article is published with open access at Springerlink.com

\begin{abstract}
Aerobic and anaerobic microbial key processes were quantified and compared to microbial numbers and morphological structure in Mediterranean sponges. Direct counts on histological sections stained with DAPI showed that sponges with high microbial abundances (HMA sponges) have a denser morphological structure with a reduced aquiferous system compared to low microbial abundance (LMA) sponges. In Dysidea avara, the LMA sponge, rates of nitrification and denitrification were higher than in the HMA sponge Chondrosia reniformis, while anaerobic ammonium oxidation and sulfate reduction were below detection in both species. This study shows that LMA sponges may host physiologically similar microbes with comparable or even higher metabolic rates than HMA sponges, and that anaerobic processes such as denitrification can be found both in HMA and LMA sponges. A higher concentration of microorganisms in the mesohyl of HMA compared to LMA sponges may indicate a stronger retention of and, hence, a possible benefit from associated microbes.
\end{abstract}

Communicated by M. Kühl.

M.-L. Schläppy · S. I. Schöttner · G. Lavik ·

M. M. M. Kuypers - D. de Beer · F. Hoffmann

Max-Planck-Institute for Marine Microbiology,

Celsiusstr. 1, 28359 Bremen, Germany

Present Address:

F. Hoffmann ( $\square)$

Sars International Centre for Marine Molecular Biology,

Thormøhlensgate 55, 5008 Bergen, Norway

e-mail: Friederike.Hoffmann@sars.uib.no

\section{Introduction}

Sponges are evolutionary ancient Metazoa, the first multicellular organisms on the tree of life. They can harbor great amounts and a large variety of microbes (see Taylor et al. 2007 for review). Microscope studies showed that, in some species, $33 \%$ of the space in the sponge tissue is occupied by microbes (Vacelet and Donadey 1977). These species have been termed 'bacteriosponge' (Reiswig 1981) or 'high microbial abundance' (HMA) sponges (Hentschel et al. 2003) and can have as many as $10^{8}-10^{10}$ cells $\mathrm{g}^{-1}$ of sponge wet weight, which is $2-4$ orders of magnitude higher than the microbial concentration in seawater. The microorganisms in HMA species are sponge-specific and differ from those in the water column in number and nature (Hentschel et al. 2003). In contrast, 'low microbial abundance' (LMA) sponges have $\leq 10^{6}$ microbes $\mathrm{g}^{-1}$ of sponge wet weight (Hentschel et al. 2003). Microorganisms can be present in the sponge matrix (mesohyl) between sponge cells, within sponge cells (Vacelet and Donadey 1977) and even within the nucleus (Friedrich et al. 1999; Vacelet 1975).

Molecular studies revealed the presence of a large variety of microbes associated to sponges, which belong to 14 different phyla (Taylor et al. 2007). Sponge-associated microorganisms are very similar across sponge species and within species across latitudinal gradients (Hentschel et al. 2002). Unfortunately, the ever-increasing knowledge of the taxonomic nature of sponge-associated microbes infers little about their metabolic function, activity and benefit to the sponge. Thus, microbially mediated biochemical processes must be uncovered if the nature of the sponge-microbe association is to be understood. To date, several microbial processes have been found in sponges: nitrification (Bayer et al. 2007; Bayer et al. 2008; Corredor et al. 1988; Diaz and Ward 1997; Jiménez and Ribes 2007; Southwell et al. 2008), nitrogen fixation 
(Wilkinson and Fay 1979; Mohamed et al. 2008), photosynthesis (Arillo et al. 1993), methane oxidation (Vacelet et al. 1996) and sulfate reduction (Hoffmann et al. 2005a).

Until recently, sponges were assumed to have an exclusively aerobic metabolism, similarly to most invertebrates. Their enormous capacity to filtrate water (e.g. Reiswig 1971) was thought to provide adequate oxygenation across the whole sponge at all times. The discovery of anaerobic microbes in Porifera led to the proposition of anoxic niches within sponges (Webster et al. 2001). When oxygen concentrations were measured with microelectrodes inside sponges, it became evident that sponges that do not ventilate become quickly anoxic. This is the case for Aplysina aerophoba (Hoffmann et al. 2008), Geodia barretti explants (Hoffmann et al. 2005a), Dysidea avara (Schläppy et al. 2007), Chondrosia reniformis (Schläppy et al. in press) and Cliona orientalis (Schönberg et al. 2004). The spatial and/or temporal anoxic microniches within the tissues of those species could result in the activation of the anaerobic microbes present in the sponge. The link between anoxia in sponges and anaerobic microbial processes was made by Hoffmann et al. (2005b) who reported the simultaneous occurrence of anoxic zones in sponge tissues and of sulfate reduction, an anaerobic microbial process, in Geodia barretti, a cold-water sponge.

Vacelet and Donadey (1977) observed that sponges with a dense mesohyl and a reduced aquiferous system host large amount of microorganisms, while species with a looser mesohyl and well developed aquiferous system host comparatively less mircroorganisms. Recently, Weisz et al. (2008) provided supporting evidence for this original observation and established that HMA sponges are denser (heavier) and have a lower pumping rate as the LMA species. In this study, we investigate whether dense tissue and a high number of associated microbes lead to more diverse microbial processes, including anaerobic ones. We present a new method of quantification, counting microbes directly on tissue sections, to determine both microbial numbers and tissue density. We chose a LMA sponge, Dysidea avara, and a HMA sponge, Chondrosia reniformis. Additionally, we included Aplysina aerophoba for which microbial cell counts using the classical sponge slurry approach were already made (Friedrich et al. 1999) and for which microbial processes have already been described (Bayer et al. 2008; Jiménez and Ribes 2007).

\section{Materials and methods}

Microbial counts and quantification of the aquiferous system

The Dysidea avara specimens came from two different locations and dates: (1) Adriatic Sea, Limski Canal, Croatia close to Rovinj, Croatia $\left(44^{\circ} 67.50^{\prime} \mathrm{N} 13^{\circ} 37.0^{\prime}\right.$ Sec.), April 2005 and (2) Northern Adriatic Sea Muntanya de Montgó, Punta del Romani at Cala Illa Mateua in the township of L'Escala, Girona, Spain $\left(42^{\circ} 06.863^{\prime} \mathrm{N} \quad 03^{\circ} 10.116^{\prime} \mathrm{E}\right)$, Northern Mediterranean in March 2006. Aplysina aerophoba and Chondrosia reniformis specimens only came from the Croatian site. Sponges were immediately fixed in $2 \%$ formalin after collection, dehydrated in a $30,50,70 \%$ ethanol series and stored in $70 \%$ ethanol. Three tissue blocks were cut from each individual, at different zones of the sponge (apex, middle and basis). Each block contained the continuum from sponge surface to sponge core. After saturation with liquid cryomedium (Jung Tissue Freeze Medium $^{\circledR}$, Leica Microsystems, Nussloch) for $12 \mathrm{~h}$ at $4{ }^{\circ} \mathrm{C}$, the blocks were trimmed into $1 \times 0.5 \mathrm{~cm}$ pieces. They were embedded in base molds with fresh cryomedium and left to harden for $12 \mathrm{~h}$ at $-80^{\circ} \mathrm{C}$. For histological analysis, $5 \mu \mathrm{m}$-longitudinal sections were made using a cryostat microtome (HM 505E, Microm, Walldorf, Germany) at $-35^{\circ} \mathrm{C}$. All sponge sections were mounted on gelatinized glass slides and prepared for microscopic analysis by using 0.2\% 4, 6-diamino-2-phenyindole (DAPI, Sigma). Since auto-fluorescence was expected to occur on the sections stained with DAPI and thus give a spurious DAPI signal, we also used a second staining method, fluorescence in situ hybridization (FISH), to confirm that the DAPI signals really represented microbial DNA. FISH was performed with sections of each species using the Cy3-labeled oligonucleotide probe mix EUB I-III (Daims et al. 1999). Formamide concentrations in the hybridization solution and washing buffer were $35 \%$ v:v. After rinsing and airdrying, the sections were mounted in Citiflour.

Microscopical analysis was first carried out (at $100 \times$ magnification) with a Zeiss Axiophot microscope equipped with Zeiss filters (for DAPI and Cy3) on the entire tissue section to obtain an overview and train visual perception. Color micrographs were taken using a Zeiss Axiolmager M1 microscope with an AxiCam MRc camera system. Digital image processing was performed using AxioVision 4.4 software. An ocular with a $122 \mu \mathrm{m} \times$ $122 \mu \mathrm{m}$-counting grid and scale bar was used for determining the proportion of different tissue types (e.g. cortex, mesohyl) and for counting of DAPI- or FISH-stained microbial cells (at $1,000 \times$ magnification). To determine microbial abundance, thirty visual fields were inspected per specimen on a transect from the sponge's surface to its core by counting 150 grid-cells per tissue block. With three tissue blocks per specimen, this reveals $n=450$ grid-cell counts for determination of microorganism numbers per specimen. A percentage estimation of the aquiferous system (proportion of choanocyte chamber and canals to mesohyl in \%) was carried out for each grid and averaged for each species. 
Microbial processes in Dysidea avara and Chondrosia reniformis

Twelve specimens of $D$. avara and $C$. reniformis were collected by SCUBA diving in 10-15 $\mathrm{m}$ water depth in Muntanya de Montgó, Punta del Romani at Cala Illa Mateua in the township of L'Escala, Girona, Spain $\left(42^{\circ} 06.863^{\prime} \mathrm{N} 03^{\circ} 10.116^{\prime} \mathrm{E}\right)$. The specimens were allowed to acclimatize for 1 day before the start of the experiments in a 20-1 aquarium with freshly sampled seawater, an air stone and re-circulating water at $15^{\circ} \mathrm{C}$. Prior to starting the denitrification and anammox incubation experiments, three specimens of each species were cut into explants of $0.2-$ $0.5 \mathrm{~g}^{-1}$ and used directly for the experiment. All specimens looked healthy at the start of the experiments.

\section{Nitrification}

The presence of nitrification (the process of $\mathrm{NH}_{4}^{+}$transformation to $\mathrm{NO}_{2}{ }^{-}$and subsequently ${ }^{-}$to $\mathrm{NO}_{3}{ }^{-}$) was tested by conducting an incubation experiment in which three specimens of $C$. reniformis and three of $D$. avara were kept in 1-1 beakers with fresh marine seawater, with an air stone and a magnetic stirrer. An additional three beakers were set up identically but without sponges as controls. The water was kept at constant temperature and in the dark. Additional ammonium $(10 \mu \mathrm{M})$ was added to each beaker. Water aliquots $(10 \mathrm{ml})$ were taken over the course of $24 \mathrm{~h}$ and immediately frozen at $-20^{\circ} \mathrm{C}$ until the start of the analyses. Ammonium was processed in an auto-analyzer while nitrite and nitrate were determined with a $\mathrm{NO}-\mathrm{NO}_{2}-\mathrm{NO}_{x}$ analyzer (Thermo Environmental Instruments Inc., USA). Aliquots of $200 \mu \mathrm{l}$ were injected in a glass chamber that contained a reduction solution (nitrite: $7.5 \mathrm{~g} \mathrm{Na}$ I mixed with $2.5 \mathrm{~g} \mathrm{H}_{3}$ $\mathrm{PO}_{4}$ 99\%; $\mathrm{NO}_{x}$ : $0.1 \mathrm{M} \mathrm{Va}(\mathrm{III}) \mathrm{Cl}$ ). The reduction solutions were made anew for each day of measurement. After passing through $2 \mathrm{M} \mathrm{NaOH}$, the $\mathrm{NO}$ gas was freed from the sample, and $\mathrm{NO}_{X}$ was measured by passing through the ozonator. The integrated area under the curve (using the ECW 2000 Integration Package) and not the peak was used to calculate the $\mathrm{NO}_{x}$ and $\mathrm{NO}_{2}{ }^{-}$content of the samples. Nitrates were calculated: $\mathrm{NO}_{x}-\mathrm{NO}_{2}{ }^{-}=\mathrm{NO}_{3}{ }^{-}$. The rate of production or consumption was calculated as the average of all three sponge replicates minus the average of the three controls.

\section{Denitrification and anammox}

Denitrification occurs through the combination of 2 moles of $\mathrm{NO}_{3}{ }^{-}$to $1 \mathrm{~mol}$ of $\mathrm{N}_{2}$. Depending on the residual ${ }^{14} \mathrm{~N}$ in the system (either through the seawater or due to sponge microbe nitrification) and when the ${ }^{15} \mathrm{NO}_{3}{ }^{-}$tracer is added, denitrification can produce $\mathrm{N}_{2}$ of any of the three combinations through random pairing: ${ }^{14} \mathrm{~N}^{14} \mathrm{~N},{ }^{14} \mathrm{~N}^{15} \mathrm{~N}$ or ${ }^{15} \mathrm{~N}^{15} \mathrm{~N}$
(Nielsen 1992). Anammox (anaerobic ammonium oxidation) combines $1 \mathrm{~mol}$ of $\mathrm{NO}_{2}{ }^{-}$with $1 \mathrm{~mol}$ of $\mathrm{NH}_{4}{ }^{+}$ion to $\mathrm{N}_{2}$. We specifically checked for anammox by using ${ }^{15} \mathrm{NH}_{4}{ }^{+}$and ${ }^{14} \mathrm{NO}_{2}{ }^{-}$as labels. Thus, anammox can yield ${ }^{14} \mathrm{~N}^{14} \mathrm{~N}$ or ${ }^{14} \mathrm{~N}^{15} \mathrm{~N}$ but not ${ }^{15} \mathrm{~N}^{15} \mathrm{~N}$ when the incubation is done with ${ }^{14} \mathrm{NO}_{2}^{-}$(Thamdrup and Dalsgaard 2002). Sponge explants of $C$. reniformis (0.3-0.9 g wet weight) and D. avara (0.02-0.4 g wet weight) were incubated in 12.5-ml gas-tight glass vials (Labco Exetainer, Labco Limited, UK) filled with natural seawater spiked with $10 \mu \mathrm{M}^{15} \mathrm{NO}_{3}{ }^{-}$for the denitrification experiment and with $10 \mu \mathrm{M}{ }^{15} \mathrm{NH}_{4}{ }^{+}$and $2 \mu \mathrm{M}{ }^{14} \mathrm{NO}_{2}{ }^{-}$for the anammox experiment. The exetainers were free of air bubbles. We estimated a respiration rate of $9 \mu \mathrm{mol} \mathrm{O}_{2} \mathrm{~cm}^{-3}$ sponge day ${ }^{-1}$ based on Hoffmann et al. (2005b) and estimated that $90 \%$ of the oxygen in the exetainers should be depleted within $24 \mathrm{~h}$ (but residual oxygen may have been present). Microbial processes were stopped at $0,2,3,6,12$ and $24 \mathrm{~h}$ for denitrification and $0,1,3,6,12$ and $24 \mathrm{~h}$ for anammox by injecting $150 \mu \mathrm{l}$ of saturated $\mathrm{HgCl}_{2}$ solution in the exetainers. Those were gently shaken for good mixing of the chemical and stored up-side-down (to avoid gas leakage) after a head space of $2 \mathrm{ml}$ of He gas was added to trap the produced $\mathrm{N}_{2}$. Samples were stored at room temperature until analyzed. Gas chromatography-isotopic ratio mass spectrometry was carried out to determine the isotope ratio $\left({ }^{14} \mathrm{~N}^{14} \mathrm{~N},{ }^{14} \mathrm{~N}^{15} \mathrm{~N}\right.$, and $\left.{ }^{15} \mathrm{~N}^{15} \mathrm{~N}\right)$ of the $\mathrm{N}_{2}$ gas trapped in the exetainers' head space by injecting $250 \mu$ l. The concentration of the different isotopic combinations was determined, and the $\mathrm{N}_{2}$ production rates were calculated from the slope of the $\mathrm{N}_{2}$ increase over time (Nielsen 1992).

\section{Sulfate reduction}

Both sulfide microelectrodes and radioactive isotopes were used in this study to detect sulfate reduction in $D$. avara and $C$. reniformis. The presence of sulfide was tested by the use of a sulfide microsensor with a 20-micron tip and a $1-\mu \mathrm{M}$ detection limit. Additionally, an incubation experiment of sponge explants was performed with ${ }^{35} \mathrm{SO}_{4}{ }^{2-}$ using a modified method of the whole core method (Jørgensen 1978). Incubation of sponge pieces was carried out in 5-ml syringes filled with 4.5-ml seawater for 0,10 , 30 , and $60 \mathrm{~min}$. The short incubation times were chosen as immediate re-oxidation of the tracer masked sulfate reduction rates in the tissue of other sponges (Hoffmann et al. 2005b). The incubations were performed with air (oxic), with argon (anoxic), and with argon and an extra carbon source that was made of a mixture of acetate, lactate, propionate and butyrate. A volume of $50 \mu \mathrm{l}$ of a $25-\mathrm{mM}$ stock solution of ${ }^{35} \mathrm{SO}_{4}{ }^{2-}$ of $600 \mathrm{KBq}$ adjusted to pH 8 with $\mathrm{NaOH}$ and was used to inject into the syringe containing the sponge. Sodium sulfate $(10 \mathrm{mM})$ was also 
added as carrier for the tracer (Fossing and Jørgensen 1989). The reaction was stopped after $0,10,30$, and $60 \mathrm{~min}$ by adding $20 \%$ zinc acetate. Reduced sulfur species were analyzed with the chromium reduction method (Fossing and Jørgensen 1989), with the two-step method.

\section{Results}

Microbial counts and prevalence of the aquiferous system

Visual training allowed the clear distinction between microbial or sponge cells. Microorganisms were visible as $<2-\mu \mathrm{m}$ "speckles" at $1,000 \times$ magnification and as characteristic FISH signals, while nuclei of the sponge cells were $\sim 5 \mu \mathrm{m}$. Choanocyte chambers were characterized by the arrangement of the choanocyte nuclei lining a lacuna, whereas canals were areas devoid of cells or any other structures (Figs. 1, 2, 3). Chondrosia reniformis' extracellular matrix was heterogeneous and very dense (Table 1) with few visible canals (Fig. 1a). Two microbial niches were found: the collagen and the mesohyl (Fig. 1b). The microbes were more abundant in the mesohyl and exhibited distinct clusters or chains of microorganisms of 4-16 $\mu \mathrm{m}$ in size (Fig. 1c, d), which were absent in the collagen. Thus, microorganism counts were carried out separately for the mesohyl $\left(2.7 \times 10^{10}\right.$ cells $\mathrm{cm}^{-3}$ sponge $)$ and collagen $\left(0.97 \times 10^{10}\right.$ cells cm ${ }^{-3}$ sponge $)$ and proved to be significantly different (chi-square, $P=0.04, \dot{\alpha}=0.05, d f=1$, with Yate's correction). Water canals were absent in the collagen and only in low numbers in the choanosome. Aplysina aerophoba showed homogenous tissue composition and high tissue density (Fig. 2a, b; Table 1). Sponge cell nuclei were evenly distributed in the mesohyl but less so in the cortex and in inclusions. The mesohyl had canals of various sizes, the choanocyte chambers $(4-20 \mu \mathrm{m}$ across, average 9-10 $\mu \mathrm{m}$; Fig. 3c) and sponge cells were uniformly scattered over the whole area. Sponge-associated microorganisms were densely packed in the mesohyl (Fig. 2d). Dysidea avara had a loose tissue composition (Fig. 3a). The choanosome was composed of choanocytes forming a giant complex of associated chambers (Fig. 3b). The microorganisms were $<1 \mu \mathrm{m}$, had a variety of morphologies and were arranged in clumps (Fig. 3c, d). The aquiferous system was most developed in $D$. avara followed by A. aerophoba and finally $C$. reniformis, which had densest body structure (Table 1). When the prevalence of the aquiferous system ('porosity') of the sponges was related to the number of microbes in the whole sponges (averages in Table 1), C. reniformis and A. aerophoba clustered separately but yet in the vicinity of each other,
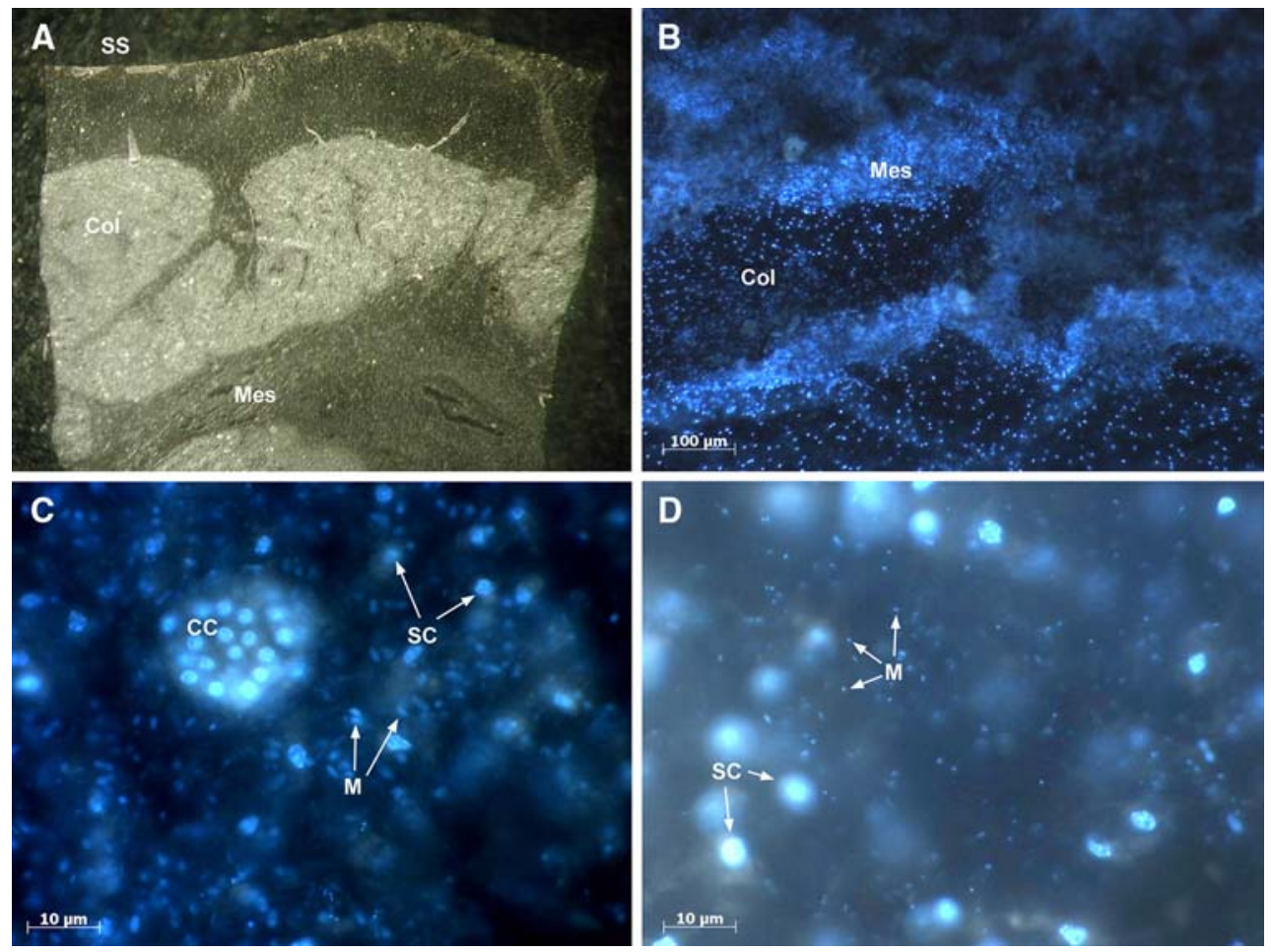

Fig. 1 Chondrosia reniformis cryo-sections a general overview, $\times 3.2$, b mesohyl and collagen overview, DAPI, $\times 100$, c mesohyl detail with choaonocyte chamber, DAPI, $\times 1,000$ and d mesohyl

detail with sponge-associated microbes and sponge cell nuclei, DAPI, $\times 1,000$. Col collagen, SS sponge surface, Mes mesohyl, CC choanocyte chamber, $S C$ sponge cell nucleus, $M$ microbe 

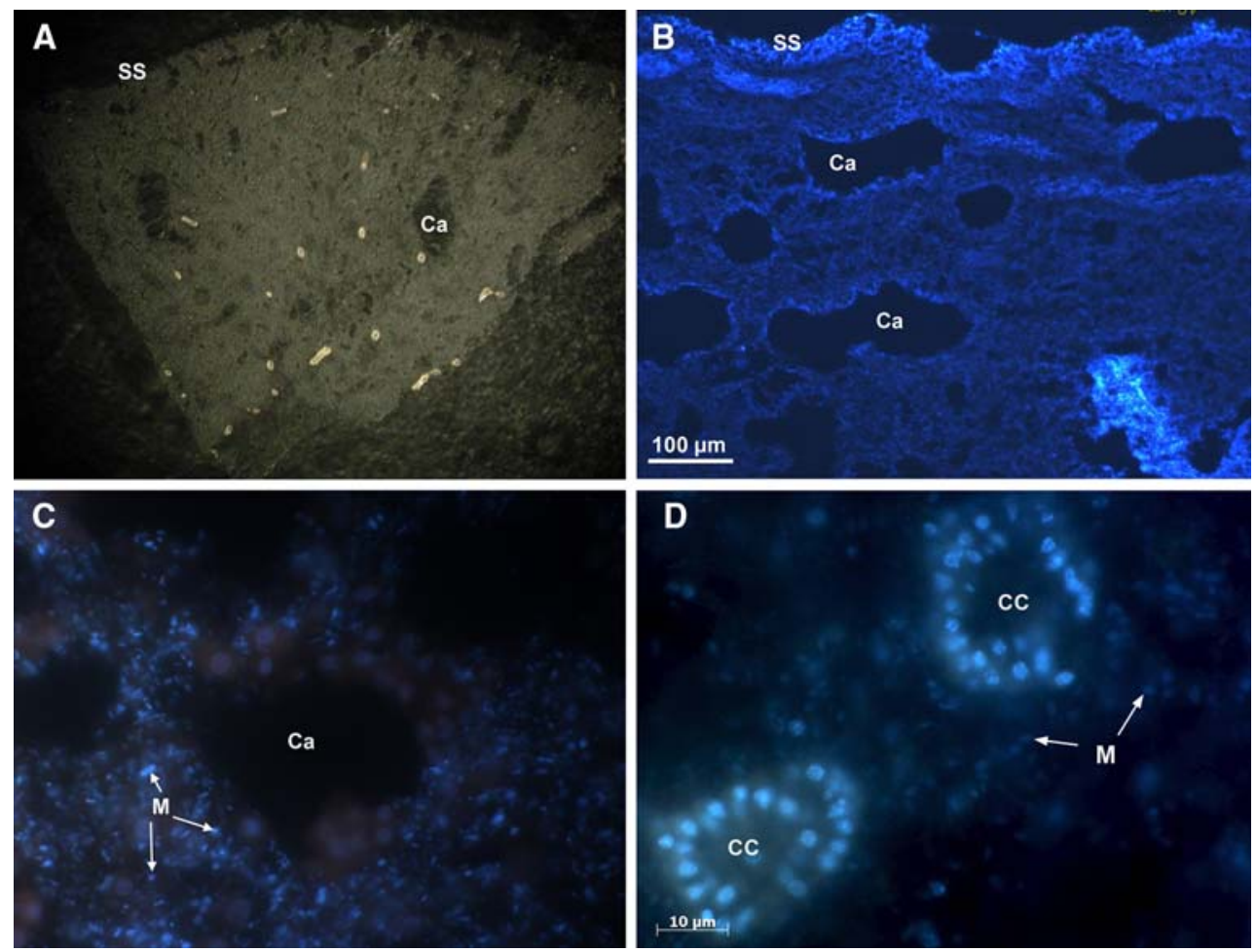

Fig. 2 Aplysina aerophoba cryo-sections a general overview, $\times 2.5$, b overview of the cortex region and of the mesohyl, DAPI, $\times 100$, c detail of the mesohyl with sponge-associated microbes, sponge cell nuclei and canals, DAPI, $\times 1,000$ and $\mathbf{d}$ detail of the mesohyl with

choanocyte chambers, DAPI, $\times 1,000$. Col collagen, SS sponge surface, Mes mesohyl, $C C$ choanocyte chamber, $C a$ canal, $S C$ sponge cell nucleus, $M$ microbe
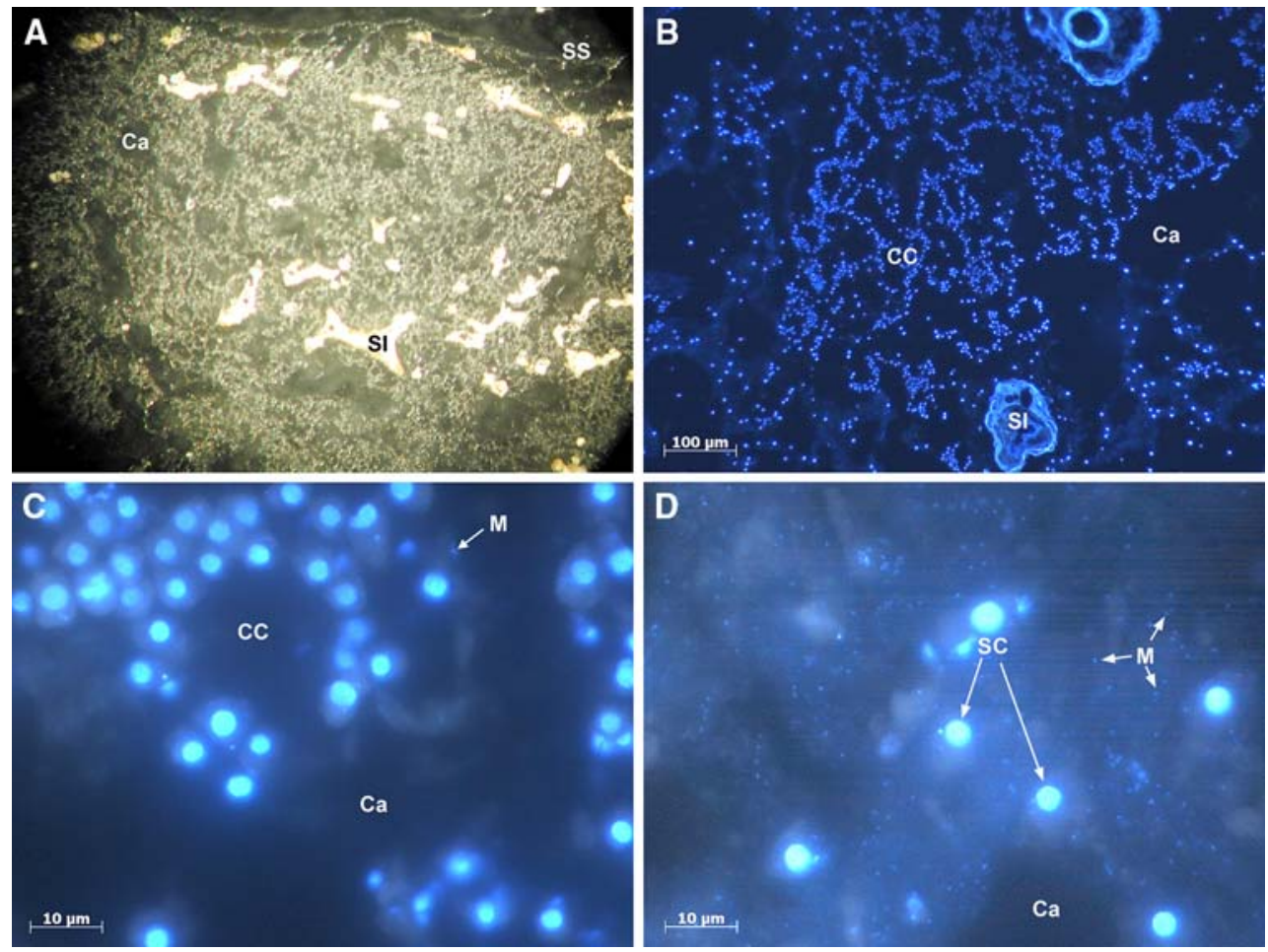

Fig. 3 Dysidea avara cryo-sections a general overview, $\times 3.2$, b choanosome with sedimentary inclusions, DAPI, $\times 100$, c choano-

detail with sponge-associated microbes and sponge cell nuclei. $\mathrm{Col}$ collagen, $S S$ sponge surface, $C C$ choanocyte chamber, $S C$ sponge cell nucleus, $M$ microbe, $S I$ sedimentary inclusion 
Table 1 Average aquiferous system in $\%$ of the whole sponge and average number of microbes $\times 10^{10} \mathrm{~cm}^{-3}$ sponge + SEM

\begin{tabular}{llll}
\hline & A. aerophoba & C. reniformis & D. avara \\
\hline$n$ & 3 & 2 & 4 \\
$\begin{array}{l}\text { Aquiferous system } \\
\% \text { of whole } \\
\text { sponge } \pm \text { SEM }\end{array}$ & $21 \pm 0.7$ & $6 \pm 1$ & $47 \pm 1$ \\
$\begin{array}{l}\text { Average number of } \\
\text { microbes } \times 10^{10} \mathrm{~cm}^{-3} \\
\text { sponge } \pm \text { SEM }\end{array}$ & $3.3 \pm 0.09$ & $2.4 \pm 0.003$ & $0.9 \pm 0.05$ \\
\hline
\end{tabular}
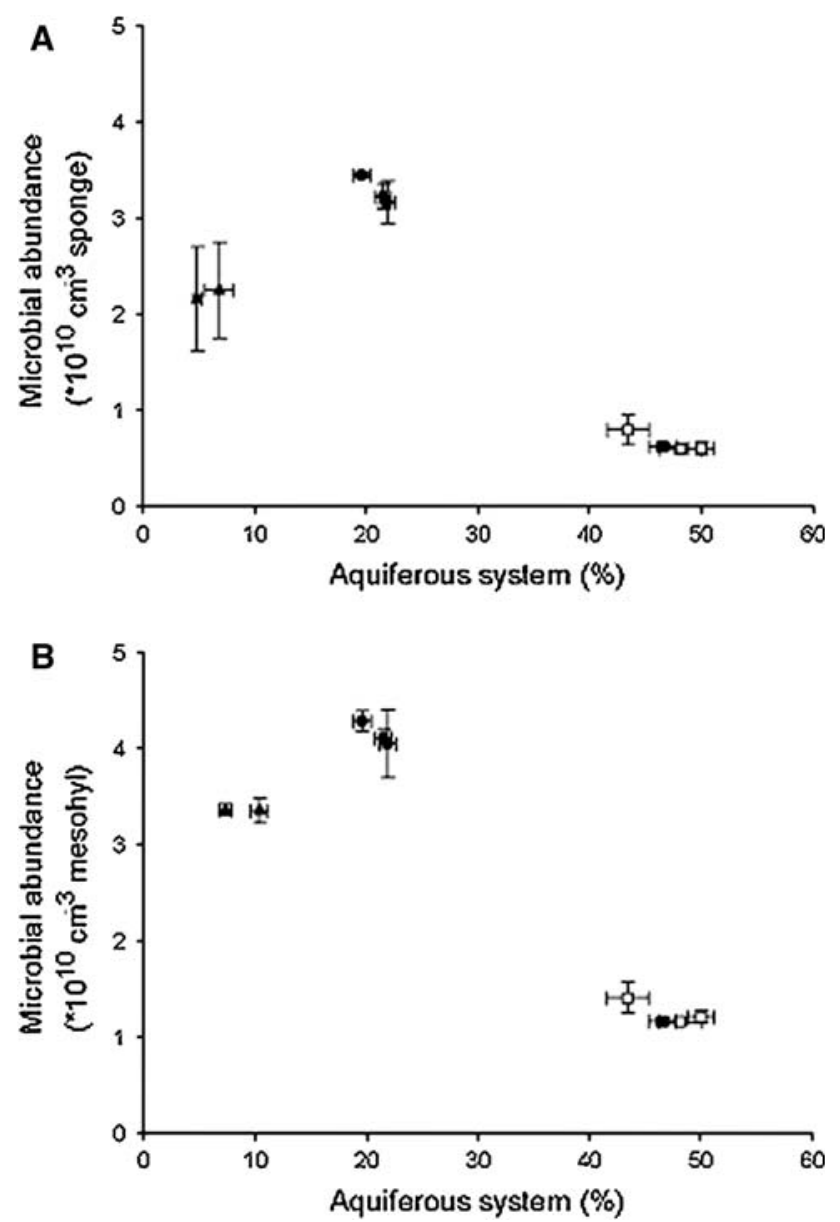

Fig. 4 Relation between aquiferous system and number of microbes $\times 10^{10}$ a in the total sponge. The error bars in C. reniformis are large because those counts include both microbial niches: collagen and mesohyl, and $\mathbf{b}$ in the mesohyl. Circles A. aerophoba, triangles $C$. reniformis, squares $D$. avara, white Rovinj, black Cala Montgo

while D. avara was separated from the HMA sponges (Fig. 4a). The same trend was observed when the porosity of the sponge was taken under consideration, which means, microbial numbers were expressed per volume of meshoyl; consequently, this resulted in higher microbial cell counts per volume (Fig. 4b).
Microbial processes

The microbial processes of nitrification and denitrification were found in both D. avara and C. reniformis (Table 2), while anammox and sulfate reduction were not detected. Ammonium, which fueled nitrification, was produced in both study species at very similar rates (Table 2). At the same time, nitrite was excreted by both sponge species but at very low rates (Table 2 and Fig. 5), which corresponded to only 0.3 and $0.4 \%$ of the ammonium excreted. Nitrate was produced in both species (Table 2 and Fig. 5) indicating net nitrification. Nitrate production rates were about ten times higher than nitrite production rates (Table 2) and corresponded to 4.2 and $5.1 \%$ of the ammonium excreted in $C$. reniformis and D. avara, respectively. Anammox being undetectable, a valid way of calculating denitrification rates was to take the slope of the $\mathrm{N}_{2}$ increase over time of the ${ }^{15} \mathrm{NO}_{3}{ }^{-}$incubation experiment (Nielsen 1992). Denitrification occurred in both study species and two types of $\mathrm{N}_{2}$ were produced: ${ }^{29} \mathrm{~N}_{2}$, resulting from the pairing of ${ }^{14} \mathrm{~N}+{ }^{15} \mathrm{~N}$, and ${ }^{30} \mathrm{~N}_{2}$, resulting from the pairing of ${ }^{15} \mathrm{~N}+{ }^{15} \mathrm{~N}$ (Fig. 6). The rates of production of ${ }^{29} \mathrm{~N}_{2}$ and ${ }^{30} \mathrm{~N}_{2}$ are shown in Table 2. Using random isotope pairing and taking both denitrification and combined nitrificationdenitrification into account, the total denitrification rate was 10 and 14.9 nmol N $\mathrm{g}^{-1}$ wet weight sponge $\mathrm{h}^{-1}$ in C. reniformis and D. avara, respectively. The net production of $\mathrm{N}_{2}$ mostly occurred after $4 \mathrm{~h}$ of incubation (Fig. 6).

\section{Discussion}

Relation between microbial abundance and aquiferous system

The extracellular matrix of $C$. reniformis had two clearly visible components: collagen and mesohyl that differed enough in their microbial composition to be analyzed separately. Chondrosia reniformis' collagen and mesohyl had significantly different amounts of microbes pointing clearly to the existence of different microbial niches within this species. This distinction did not arise in A. aerophoba and $D$. avara where the whole extracellular matrix was one single microbial habitat. The occurrence of microbes in the collagen of $C$. reniformis was unexpected, and the presence of these two well-defined sponge environments holds various implications. From a purely methodological point of view, it is clear that the use of 'slurries' to assess microbial abundance in sponges may obscure tissue heterogeneity and would have, in the case of $C$. reniformis, yielded lower estimates. Though we do not know about any possible origin or function of microbes in the collagen fibers, we assume that the different tissue types may harbor different 
Table 2 Microbial processes and rates in Chondrosia reniformis and Dysidea avara

\begin{tabular}{|c|c|c|c|c|c|c|c|}
\hline \multicolumn{5}{|c|}{ nmol $\mathrm{N} \mathrm{cm}^{-3}$ sponge $\mathrm{h}^{-1}$} & \multicolumn{3}{|c|}{ nmol $\mathrm{N} \mathrm{cm}^{-3}$ sponge $\mathrm{h}^{-1}$} \\
\hline & $\mathrm{NH}_{4}^{+}$ & $\mathrm{NO}_{2}^{-}$ & $\mathrm{NO}_{3}^{-}$ & Total net nitrification & ${ }^{29} \mathrm{~N}_{2}$ & ${ }^{30} \mathrm{~N}_{2}$ & $\overline{\text { Total net denitrification }}$ \\
\hline C. reniformis & 195.8 & 0.8 & 8.0 & 8.8 & 4.9 & 4.9 & 10 \\
\hline D. avara & 241.7 & 0.8 & 13.9 & 14.7 & 4.9 & 10 & 14.9 \\
\hline
\end{tabular}

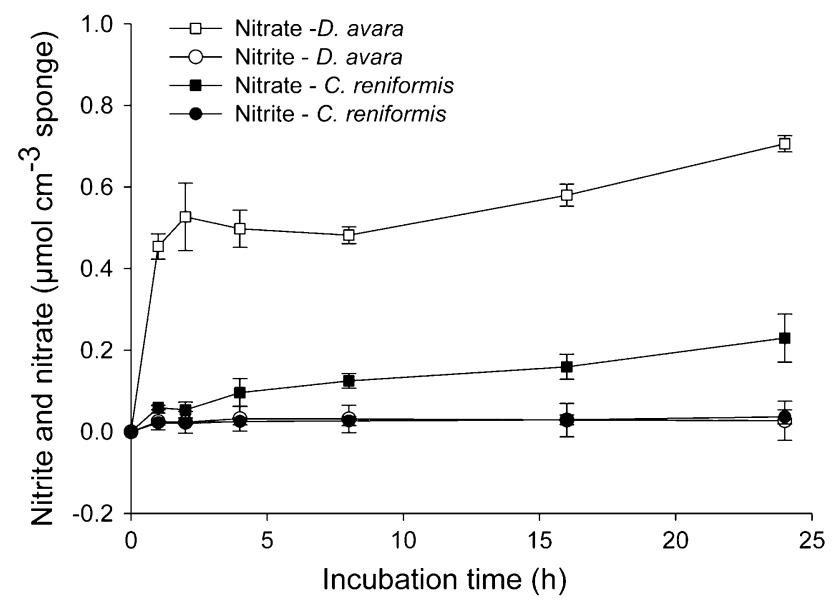

Fig. 5 Incubation of $C$. reniformis and $D$. avara with $10 \mu \mathrm{M}$ ${ }^{15} \mathrm{NO}_{3}{ }^{-}$: production of nitrite and nitrate per $\mathrm{cm}^{3}$ sponge as average water concentrations in three replicate incubations minus concentration in control incubations divided by sponge volume at a given point in time. Nitrite was produced in very low rates and nitrate in higher rates for both sponges, and revealed total nitrification rates of 14.7 and $8.8 \mathrm{nmol} \mathrm{cm}{ }^{-3}$ sponge day ${ }^{-1}$ for D. avara and C. reniformis, respectively

microbial communities due to the variability in the availability of nutrients, oxygen and space. In C. reniformis, we observed differences in the size and the morphotype of microbes in the collagen $(0.2 \mu \mathrm{m}$, rods, vibrio-shaped) compared to those in the choanosome (rods, $2 \mu \mathrm{m}$ ), which suggests strongly that the two different tissue types have different abilities in the uptake and maintenance of spongeassociated microbes. In view of our results (and using visual training with both FISH and DAPI stains to recognize typical microbes), we feel confident that our method not only yields representative counts of microbes in sponges but also allows the detection of potential microbial niches (i.e. collagen versus mesohyl) within sponge tissues.

Our new method of assessing microbial abundance yields substantially higher counts than the often used 'slurry' method. Friedrich et al. (2001) reported microbial abundance of $6.4 \pm 4.6 \times 10^{8} \mathrm{~g}^{-1}$ sponge tissue in Aplysina aerophoba, while we found an average of $3.3 \pm 0.09$ $\mathrm{SEM} \times 10^{10}$. Further, D. avara has been qualified as being 'virtually free of microorganism symbionts' in a study done with a transmission electron microscope (Turon et al. 1997) but our results show D. avara as having microbial

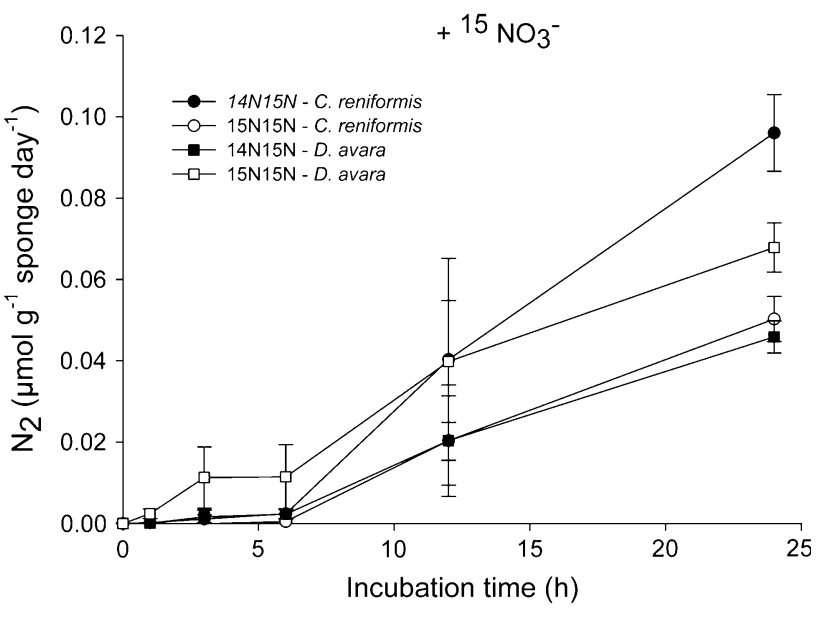

Fig. 6 Production of ${ }^{14} \mathrm{~N}^{15} \mathrm{~N}$ and ${ }^{15} \mathrm{~N}^{15} \mathrm{~N}$ after addition of $10 \mu \mathrm{M}$ ${ }^{15} \mathrm{NO}_{3}$ (with standard error of the mean) indicates denitrification in $C$. reniformis and D. avara

numbers three orders of magnitude higher $\left(10^{9} \mathrm{~cm}^{-3}\right.$ sponge) than seawater $\left(\sim 10^{6}\right)$ and are therefore in line with sediments $\left(4 \times 10^{9} \mathrm{~cm}^{-3}\right.$, Llobet-Brossa et al. 1998).

The inspection of tissue sections of three Mediterranean sponges, A. aerophoba, C. reniformis and D. avara revealed that high-microbial abundance (HMA) sponges (A. aerophoba and $C$. reniformis) have a considerably smaller aquiferous system than low microbial abundance (LMA) sponges and also denser tissues. D. avara (a LMA sponge), in contrast, had a highly developed aquiferous system and far fewer microbes than the two other species (Fig. 4a). These findings are consistent with previous observations and support the idea that two different life strategies exist in sponges (e.g. Vacelet and Donadey 1977; Weisz et al. 2008). Our data, moreover, clearly shows that the reason for the high abundance of microbes is not only related to habitat availability (i.e. more mesohyl volume per sponge volume in species where the aquiferous system is reduced) but that the habitat present (sponge mesohyl) is also more densely populated in sponges with a reduced aquiferous system. Within the HMA sponges, however, the relationship is not entirely consistent because A. aerophoba had the larger aquiferous system of the two HMA and the most microbes in the mesohyl. Other unknown factors must be playing a role in determining the number of microbes than the sponge tissue density alone. 
Table 3 Original net nitrification rates converted into other units for comparison purposes assuming dry weight $=10 \%$ of wet weight and assuming $1.2 \mathrm{~g}$ wet weight $=1 \mathrm{~cm}^{-3}$

\begin{tabular}{|c|c|c|c|c|c|}
\hline Target spp. & $\begin{array}{l}\text { This study } \\
\left(\mu \mathrm{mol} \mathrm{g}^{-1} \text { wet }\right. \\
\left.\text { weight sponge day }{ }^{-1}\right)\end{array}$ & $\begin{array}{l}\text { Bayer et al. (2007) } \\
\left(\mu \mathrm{mol} \mathrm{g}{ }^{-1} \text { wet }\right. \\
\left.\text { weight sponge day }{ }^{-1}\right)\end{array}$ & $\begin{array}{l}\text { This study } \\
\left(\mathrm{nmol} \mathrm{g}^{-1} \text { dry }\right. \\
\left.\text { weight } \mathrm{h}^{-1}\right)\end{array}$ & $\begin{array}{l}\text { Jiménez and Ribes (2007) } \\
\left(\mathrm{nmol} \mathrm{g}^{-1} \text { dry }\right. \\
\left.\text { weight } \mathrm{h}^{-1}\right)\end{array}$ & $\begin{array}{l}\text { Bayer et al. (2008) } \\
\left(\text { nmol g }{ }^{-1} \text { dry }\right. \\
\left.\text { weight } \mathrm{h}^{-1}\right)\end{array}$ \\
\hline C. reniformis & 0.176 & 0 & 73.33 & 702 & A. aerophoba 89-344 \\
\hline D. avara & 0.294 & $\sim 0.3$ & 122.5 & 0 & \\
\hline
\end{tabular}

The link between anatomy and microbial load has been attributed to the nutritional strategy of the sponge (Vacelet and Donadey 1977). Species with a well developed aquiferous system (Vacelet and Donadey 1977), large choanocyte chambers (Boury-Esnault et al. 1990) and higher pumping rates (Weisz et al. 2008) are thought to rely predominantly on capture of particulate organic matter, while those with a less pronounced aquiferous system are thought to host more microbes and subsequently use them as a food source ("microbial farming"). Our observation of higher microbial densities $\mathrm{cm}^{-3}$ mesohyl in HMA species supports this idea; we have, however, no proof yet if our target sponges also consume their associated microbes.

\section{Microbial processes}

Our aim was to investigate whether dense tissue and a high number of associated microbes may lead to more diverse microbial processes and higher rates. In this study, we found nitrification and denitrification rates in both $C$. reniformis (a HMA species) and D. avara (a LMA species), while anammox and sulfate reduction were not detected. Furthermore, nitrification, denitrification and ammonium production were highest in D. avara, the LMA species (Table 2). The absence of sulfate reduction was surprising. Anoxic conditions are known to occur in both $C$. reniformis (Schläppy et al. in press) and in D. avara (Schläppy et al. 2007) and sulfate reducers were found through the use of a specific FISH probe in C. reniformis (Schumann-Kindel et al. 1997). One possible explanation is the rapid re-oxidation of the reduced sulfide that has been shown to occur in another sponge species (Hoffmann et al. 2005b). Alternatively, sulfate reduction may be inhibited through the production of nitrite and nitrate by the nitrifiers, which fuel high rates of denitrification (as measured in this study) and out-compete sulfate reduction. Finally, it is possible that some sponges can specifically inhibit sulfate reduction to prevent accumulation of toxic sulfide, the end product of microbial sulfate reduction.

Nitrite and nitrate were produced in both $C$. reniformis and $D$. avara indicating that the nitrifiers were active. The two nitrification steps $\left(\mathrm{NH}_{4}{ }^{-}\right.$to $\mathrm{NO}_{2}{ }^{-}$to $\left.\mathrm{NO}_{3}{ }^{-}\right)$were identified and therefore reveal the presence and activity of both ammonium oxidizing and nitrite oxidizing microbes (only very little nitrite was detected). Nitrification has been shown by Bayer et al. (2007) for D. avara and C. reniformis but denitrification is shown here for the first time in Mediterranean sponges. The only other evidence of denitrification in sponges is in Geodia barretti, a cold-water species (Hoffmann et al. 2009), with $92 \mathrm{nmol} \mathrm{N} \mathrm{cm}^{-3}$ day, equals $3.8 \mathrm{nmol} \mathrm{N} \mathrm{cm}^{-3} \mathrm{~h}^{-1}$. Our rates are more than double of those found in $G$. barretti, with 10 and $14.9 \mathrm{nmol} \mathrm{N} \mathrm{cm}{ }^{-3} \mathrm{~h}^{-1}$.

The total net nitrification rates reported in this study are in the range of those reported by other authors for our target species although they are highly variable (Table 3). Those results do not take into account the anaerobic loss of nitrate through denitrification, hence, they are only indicative of net nitrification and definitely represent an underestimate of total nitrification in these sponges. The presence of denitrification may explain some of the variability in the nitrification results. Our rates of denitrification are very close to the nitrification rate, which indicates that approximately half the nitrate produced by the sponge is re-used for denitrification. The nitrifiers remove only a small portion (about $5 \%$ ) of the ammonium produced, the rest being presumably expelled through ventilation by the sponge. The rather large ammonium production may not only be a product of sponge respiration but also of fermentation processes in times of anoxia. The fact that both nitrification and denitrification occur simultaneously was apparent in the comparatively high rate of ${ }^{29} \mathrm{~N}_{2}$ produced. It could only stem from unlabeled $\mathrm{NO}_{3}{ }^{-}$, the source of which can either be the seawater in which the sponge were incubated in or, more likely, the nitrification activity of sponge-associated microbes. This co-occurrence of two microbial processes may be similar in the other species of sponges for which nitrification rates have been reported (Southwell et al. 2008). Temporal and spatial occurrence of oxic and anoxic zones within the sponge would favor both the nitrifiers and the denitrifiers, in turn. The occurrence of nitrification and denitrification suggests strongly that the microbial community inside our study species is able to deal with shifts from aerobic to anaerobic conditions inside the sponge. Furthermore, the co-occurrence of nitrification and denitrification might explain the variations in $\mathrm{NO}_{3}{ }^{-}$production seen in some species (Bayer et al. 2008). 
We conclude that both HMA and LMA sponges host an active community of microbes with nitrification and denitrification. Total rates of microbial processes in LMA sponge can be even higher than in HMA sponges. The main benefit to the sponge of having such a guild of microbes may reside in the fact that they get rid of ammonium and nitrite (which could be deleterious to the sponge) and that microbial denitrification may out-compete microbial sulfate reduction, which yields toxic sulfide. The sponge, by controlling its pumping activity, has a means of controlling the activity of both the nitrifiers and denitrifiers populations. It is also possible that the presence of autotrophic nitrifiers and heterotrophic denitrifiers provide the sponge with an optimized system for food utilization and storage under both aerobic and anaerobic conditions, in case it actually does feed on the associated microbes (something that is still to be proven). Our results show that both LMA and HMA sponges may host metabolically diverse and active microbial communities, and that anaerobic and aerobic processes can be found in both sponge types. Higher numbers of microbes per volume of mesohyl in HMA sponges may indicate a stronger retention of and, hence, a possible benefit from associated microbes.

Acknowledgments This study was funded through the EU project 017800 SPONGES (Sustainable production, Physiology, Oceanography, Natural products, Genetics and Economics of Sponges). Sponges were collected during collaboration with Prof. Maria J. Uriz Lespe and Dr. Sònia de Caralt from the Centro de Estudios Avanzados de Blanes (CEAB) from the Consejo Superior de Investigaciones Cientificas (CSIC), Spain and during collaboration with Prof. Franz Brümmer, University of Stuttgart, Germany, on the occasion of a field work carried out at the Ruder Boskovic Institute in Rovinj, Croatia.

Open Access This article is distributed under the terms of the Creative Commons Attribution Noncommercial License which permits any noncommercial use, distribution, and reproduction in any medium, provided the original author(s) and source are credited.

\section{References}

Arillo A, Bavestrello G, Burlando B, Sara M (1993) Metabolic integration between symbiotic cyanobacteria and sponges: a possible mechanism. Mar Biol 117:159-162

Bayer K, Schmitt S, Hentschel U (2007) Microbial nitrification in Mediterranean sponges: possible involvement of ammoniaoxidizing betaproteobacteria. In: Custódio MR, Lôbo-Hajdu G, Hajdu E, Muricy G (eds) Porifera research: biodiversity, innovation, sustainability. Série Livros, Museu Naciona, Rio de Janeiro, pp 165-171

Bayer K, Schmitt S, Hentschel U (2008) Physiology, phylogeny and in situ evidence for bacterial and archaeal nitrifiers in the marine sponge Aplysina aerophoba. Environ Microbiol 10:2942-2955

Boury-Esnault N, De Vos L, Donadey C, Vacelet J (1990) Ultrastructure of choanosome and sponge classification. In: Rutzler K (ed) New perspectives in sponge biology. Smithsonian Institution Press, Washington, DC
Corredor JE, Wilkinson CR, Vicente VP, Morell JM, Otero E (1988) Nitrate release by Caribbean reef sponges. Limnol Oceanogr 33:114-120

Daims H, Brühl A, Amann R, Schleifer K-H, Wagner M (1999) The domain-specific probe EUB338 is insufficient for the detection of all Bacteria: Development and Evaluation of a more comprehensive probe set. Syst Appl Microbiol 22:434-444

Diaz MC, Ward BB (1997) Sponge-mediated nitrification in tropical benthic communities. Mar Ecol Prog Ser 156:97-107

Fossing H, Jørgensen BB (1989) Measurement of bacterial sulfate reduction in sediments: evaluation of a single-step chromium reduction method. Biogeochemistry 8:205-222

Friedrich AB, Merkert H, Fendert T, Hacker J, Proksch P, Hentschel $\mathrm{U}$ (1999) Microbial diversity in the marine sponge Aplysina cavernicola (formerly Verongia cavernicola) analyzed by fluorescence in situ hybridization (FISH). Mar Biol 134:461-470

Friedrich AB, Fischer I, Proksch P, Hacker J, Hentschel U (2001) Temporal variation of the microbial community associated with the mediterranean sponge Aplysina aerophoba. FEMS Microbiol Ecol 38:105-113

Hentschel U, Hopke J, Horn M, Friedrich AB, Wagner M, Hacker J, Moore BS (2002) Molecular evidence for a uniform microbial community in sponges from different oceans. Appl Environ Microbiol 68:4431-4440

Hentschel U, Fieseler L, Wehrl M, Gernert C, Steinert M, Hacker J, Horn M (2003) Microbial diversity of marine sponges. In: Müller WEG (ed) Marine molecular biotechnology. Springer, Berlin, pp 59-88

Hoffmann F, Larsen O, Rapp HT, Osinga R (2005a) Oxygen dynamics in choanosomal sponge explants. Mar Biol Res $1: 160-163$

Hoffmann F, Larsen O, Thiel V, Rapp HT, Pape T, Michaelis W, Reitner J (2005b) An anaerobic world of sponges. Geomicrobiol J 22:1-10

Hoffmann F, Røy H, Bayer K, Hentschel U, Pfannkuchen M, Brümmer F, de Beer D (2008) Oxygen dynamics and transport in the Mediterranean sponge Aplysina aerophoba. Mar Biol 153:1257-1264

Hoffmann F, Radax R, Woebken D, Holtappels M, Lavik G, Rapp HT, Schläppy M-L, Schleper C, Kuypers MMM (2009) Complex nitrogen cycling in the sponge Geodia barretti. Environ Microbiol 11:2228-2243

Jiménez E, Ribes M (2007) Sponges as a source of dissolved inorganic nitrogen: nitrification mediated by temperate sponges. Limnol Oceanogr 52:948-958

Jørgensen BB (1978) A comparison of methods for the quantification of bacterial sulfate reduction in coastal marine sediments. II. Calculation from mathematical model. Geomicrobiol J 1:29-47

Llobet-Brossa E, Rosselló-Mora R, Amann R (1998) Microbial community composition of Wadden Sea sediments as revealed by fluorescence in situ hybridisation. Appl Environ Microbiol 64:2691-2696

Mohamed NM, Colman AS, Tal Y, Hill RT (2008) Diversity and expression of nitrogen fixation genes in bacterial symbionts of marine sponges. Environ Microbiol 10:2910-2921

Nielsen LP (1992) Denitrification in sediment determined from nitrogen isotope pairing. Fed Eur Microbiol Soc 86:357-362

Reiswig HM (1971) Particle feeding in natural populations of three marine demosponges. Biol Bull 141:568-591

Reiswig HM (1981) Partial carbon and energy budgets of the bacteriosponge Verongia fistularis (Porifera: Demospongiae) in Barbados. Mar Ecol Prog Ser 2:273-293

Schläppy M-L, Hoffmann F, Røy H, Wijffels RH, Mendola D, Sidri M, de Beer D (2007) Oxygen dynamics and flow patterns of Dysidea avara (Porifera:Demospongiae). J Mar Biol Assoc UK 86:1677-1682 
Schläppy ML, Weber M, Mendola D, Hoffmann F, de Beer D (in press) Heterogeneous oxygenation resulting from active and passive flow in two Mediterranean sponges. Limnol Oceanogr

Schönberg CHL, Hoffmann F, Gatti S (2004) Using microsensors to measure sponge physiology. Bollettino dei Musei e degli Istituti Biologici dell' Universitá die Genova 68:593-604

Schumann-Kindel G, Bergbauer M, Manz W, Szewyk U, Reitner J (1997) Aerobic and anaerobic microorganisms in modern sponges: a possible relationship to fossilization-processes. Facies $36: 268-272$

Southwell MW, Popp BN, Martens CS (2008) Nitrification controls on fluxes and isotopic composition of nitrate from Florida Key sponges. Mar Chem 108:96-108

Taylor MW, Radax R, Steger D, Wagner M (2007) Sponge-associated microorganisms: evolution, ecology and biotechnological potential. Microbiol Mol Biol Rev 71:259-347

Thamdrup B, Dalsgaard T (2002) Production of N2 through anaerobic ammonium oxidation coupled to nitrate reduction in marine sediments. Appl Environ Microbiol 68:1312-1318

Turon X, Galera J, Uriz MJ (1997) Clearance rates and aquiferous systems in two sponges with contrasting life-history strategies. J Exp Zool 278:22-36
Vacelet J (1975) Electron-microscopical study of the association between Bacteria and sponges of the genus Verongia (Dictyoceratida). Journal de microscopie et de biologie cellulaire 23:271-288

Vacelet J, Donadey C (1977) Electron microscope study of the association between some sponges and bacteria. J Exp Mar Biol Ecol 30:301-314

Vacelet J, Fiala-Medioni A, Fisher CR, Boury-Esnault N (1996) Symbiosis between methane-oxidizing bacteria and a deep-sea carnivorous cladorhizid sponge. Mar Ecol Prog Ser 145:77-85

Webster NS, Watts JEM, Hill RT (2001) Detection and phylogenetic analysis of novel Crenarchaeota and Euryarchaeota 16S Ribosomal RNA gene sequences from a Great Barrier Reef sponge. Mar Biotechnol 3:600-608

Weisz JB, Lindquist N, Martens CS (2008) Do associated microbial abundances impact marine demosponge pumping rates and tissue densities? Oecologia 155:367-376

Wilkinson CR, Fay P (1979) Nitrogen fixation in coral reef sponges with symbiotic cyanobacteria. Nature 279:527-529 